Tomasz Mika

Poznań

\title{
Kazania świętokrzyskie jako obiekt badań filologicznych Pytania o tekst i przekaz
}

Chciałbym inspirowany tematem naszego spotkania: Geneza, przekaz, tekst, kontekst - po lekturze nowej edycji, podjąć zagadnienie przekazu i tekstu Kazań świętokrzyskich, zatem skupić się na kazaniach rozumianych - zgodnie z tematem mojego wystąpienia - jako obiekt badań filologicznych. Chciałbym również zastanowić się, na ile obrana metoda postępowania $\mathrm{z}$ obiektem badań determinuje wyciągane na tej podstawie wnioski.

Gdyby ktoś pokusił się o wskazanie wśród zachowanych do dziś polskich tekstów średniowiecznych takiego, któremu poświęcono najwięcej miejsca w pracach naukowych, musiałby wybierać pomiędzy dwoma Bogurodzica i Kazaniami świętokrzyskimi. Te same dzieła trzeba by wziąć pod uwagę, wskazując teksty najbardziej kontrowersyjne, w odniesieniu do których sformułowano najwięcej hipotez sprzecznych. Doskonale pokazuje to dyskutowane tutaj nowe wydanie Kazań swiętokrzyskich w Bibliotece Narodowej ${ }^{1}$. Jeszcze bardziej znaczące jest zatytułowanie części opisowej w tejże edycji wspólnym nagłówkiem „Propozycje badawcze”2. Widać wyraźnie, że wydawcy - Paweł Stępień i współpracujące z nim Halina Tchórzewska-Kabata oraz Izabela Winiarska-Górska - zrezygnowali z mającego wiele lat obyczaju, by obszerny wstęp do wydania BN był przede wszystkim rekapitulacją ustaleń, sprawozdaniem z obowiązującego stanu wiedzy (wymogowi temu czyni zadość rozprawa $Z$ dziejów

1 „Kazania świętokrzyskie”. Nowa edycja...

2 Tamże, s. 11. 
badań nad „Kazaniami świętokrzyskimi”’3). Znaczące jest też powierzenie napisania wstępu reprezentantom różnych dziedzin: paleografowi-kodykologowi (Wiesław Wydra), badaczowi retoryki (Marek Skwara), historykowi literatury (Paweł Stępień), filologowi klasycznemu, znawcy łaciny średniowiecznej (Mieczysław Mejor) i wreszcie polonis-tom-językoznawcom (Izabela Winiarska-Górska, Katarzyna Skowronek, Wacław Twardzik i autor niniejszego szkicu). Widać wyraźnie, że wydawcy mają świadomość, że Kazania świętokrzyskie wciąż zmuszają do stawiania pytań i że niewiele dotychczas na nie udzielono pewnych odpowiedzi.

Nowe wydanie skłania do dyskusji - pokazuje, jak daleko do znalezienia wspólnego zdania w wielu fundamentalnych obszarach. Uświadamia też, że zastosowanie różnych metod badawczych prowadzi do rozbieżnych wniosków. Przykładem niech będzie zagadnienie domniemanego odbiorcy kazań: historyk literatury (Paweł Stępień) podtrzymuje swoje przekonanie, że są nim kaznodzieje, kodyklog-paleograf (Wiesław Wydra) zastanawia się, czy „ktoś stojący niżej w hierarchii kościelnej” nie „przygotowywał komuś zajmującemu wyższe stanowiskowe kazania do wygłoszenia”, badacz retoryki (Marek Skwara) widzi w nich „ludzi prostych i słabo wykształconych".

Nawet wydawałoby się, że postulat tak oczywisty, by kazania traktować - żeby użyć słów Tadeusza Witczaka - jako „twór dwujęzyczny”", nie jest przez współautorów nowego wydania jednomyślnie respektowany. Pokazuje to na przykład analiza statystyczna leksyki kazań ${ }^{5}$ - obejmująca wyłącznie słownictwo polskie. A przecież dwujęzyczność kazań polega nie tylko na współwystępowaniu fragmentów napisanych po polsku i fragmentów łacińskich, ale także na nierozerwalnej dwujęzyczności fraz i świadomym wykorzystywaniu obu języków ${ }^{6}$. Wreszcie lektura nowego wydania pokazuje rzecz z pozoru oczywistą, że niektóre fundamentalne pytania można postawić wyłącznie z określonej perspektywy dla innych ujęć pozostają zakryte. I tak w centrum zainteresowania Wie-

3 Tamże, s. $13-40$.

${ }^{4}$ T. Witczak, „Kazania świętokrzyskie”, hasło [w:] Dawni pisarze polscy od początków piśmiennictwa do Mtodej Polski. Przewodnik biograficzny i bibliograficzny, t. 2, Warszawa 2001, s. 110.

${ }^{5}$ K. Skowronek, „Kazania świętokrzyskie” - liczby i stowa, [w:] „Kazania świętokrzyskie”. Nowa edycja..., s. 167-176.

${ }^{6}$ Por. M. Mejor, Eacina w „Kazaniach świętokrzyskich”, [w:] „Kazania świętokrzyskie”. Nowa edycja..., s. 85-87; por. też T. Mika, Tajemnice „Kazań świętokrzyskich”, „Teraz”, 2006 , nr 1 (25), s. 15. Więcej na ten temat piszę w przygotowywanej do druku książce poświęconej Kazaniom świętokrzyskim. 
sław Wydra stawia problem integralności tekstu: traktując kazania jako kopię z kopii zastanawia się, czy części ich materii słownej nie stanowią wciągnięte do tekstu przez kopistę glosy. Tego zagadnienia nie podejmują pozostali badacze. Zatem każde z ujęć kształtuje w sobie właściwy sposób obiekt badań. Dotyczy to oczywiście także piszącego te słowa mam świadomość, że moje ujęcie tekstu jest profilowane zarówno uprawianą dziedziną, jak i zagadnieniami, które przyszło mi podjąć - Kazaniami Świętokrzyskimi zajmuję się od czasu, kiedy kilka lat temu zostałem zaproszony do współpracy w realizacji grantu KBN realizowanego przez Pracownię Języka Staropolskiego IJP PAN w Krakowie: „Biblioteka zabytków polskiego piśmiennictwa średniowiecznego"7. Moja rola polegała na zaproponowaniu interpunkcji w transkrypcji między innymi Kazań świętokrzyskich. To zadanie poprowadziło mnie w kilku zazwyczaj nie łączonych ze sobą kierunkach (co zadecydowało sposobie patrzenia na ten tekst). $\mathrm{Z}$ jednej strony, wstawiając do tekstu - zgodnie z dyrektywą Zasad wydawania tekstów staropolskich ${ }^{8}$ - interpunkcję według współczesnych reguł, musiałem się kierować względami składniowymi, z drugiej, zajmując się delimitacją tekstu, nie sposób było pominąć jego fizycznej postaci i nie podjąć refleksji nad interpunkcją średniowieczną, zawartą w rękopisie. Ta zaś, jak wiadomo, w największym stopniu uwarunkowana była regułami sztuki dyktamenu i służyła przygotowaniu tekstu do wygłoszenia, co prowadzi w stronę retoryki.

$Z$ jednej strony zatem składnia - tradycyjnie badana „na transkrypcji”, z drugiej - właściwości rękopisu nieustannie konfrontowanego z transliteracją, z trzeciej - względy retoryczne. Konieczność patrzenia na Kazania świętokrzyskie z różnych perspektyw prowadzi do problemu tekstu traktowanego jako obiekt badań i do pytania, jak on się przedstawia badaczom prezentującym różne dziedziny.

Nie od dziś wiadomo, że transkrypcja jest interpretacją. (Wystarczy powiedzieć, że obecna edycja proponuje - w transkrypcji - podział tekstu na znacznie dłuższe zdania, niż wszystkie poprzednie, inaczej też w niej uzupełniono wiele miejsc uszkodzonych). Badania prowadzone na transkrypcji są zatem pracą prowadzoną na cudzej interpretacji tekstu średniowiecznego - na swoistym jego przekazie. Czy można więc po-

${ }^{7}$ Biblioteka zabytków polskiego piśmiennictwa średniowiecznego [płyta DVD - projekt badawczy nr PBZ-KBN-064/H01/2001], Instytut Języka Polskiego PAN, Kraków 2006. Profesorowi Wacławowi Twardzikowi dziękuję tak za zaproszenie do realizacji tego zadania, jak i za dyskusję niemal nad każdym wstawianym do transkrypcji kazań znakiem interpunkcyjnym.

${ }^{8}$ Zasady wydawania tekstów staropolskich. Projekt, Wrocław 1955, s. 41 i 89. 
wiedzieć, że będą one prowadziły do poprawnego opisu i interpretacji tekstu tylko wtedy, kiedy transkrypcja będzie prawidłowa? Czy inaczej wnioskowanie naukowe stanie się interpretacją interpretacji (uwspółcześnionego przekazu), a nie tekstu średniowiecznego?

Trudno jednak wyobrazić sobie rezygnację z transkrypcji - dla nienaukowego odbiorcy jest ona najdostępniejszym przekazem tekstu, a dla reprezentantów wielu dziedzin nauki wydaje się ona wystarczającym obiektem badań. Dla innych badaczy na pierwszym miejscu stanie transliteracja. Coraz częściej słyszy się głosy, że i ona jest interpretacją, a spory nad oczytaniem niektórych fragmentów Kazań swiętokrzyskich trwały do ostatnich chwil przed oddaniem najnowszego wydania do druku i nie wszystkie wydają się ostatecznie rozstrzygnięte. Ostatecznie więc, co mam na myśli, mówiąc, że badam tekst Kazań świętokrzyskich?

Wypada się zastanowić, do jakiego sposobu obserwacji obiektu zdaje się zapraszać nowa edycja Kazań świętokrzyskich - przez przyjęty sposób prezentacji samego tekstu: równoległe zestawienie nowej transliteracji z rękopisem (znacząco różniącej się od odczytań wcześniejszych), równoległe zestawienie transliteracji z filologicznym tłumaczeniem partii łacińskich, wreszcie przez przypisy do obu postaci tekstu i indeks, a także skrupulatne zestawienie różnic pomiędzy dotychczasowymi transkrypcjami i transliteracjami. Intencja twórców takiego układu edycji jest czytelna: transliteracja i transkrypcja nie są w niej prezentowane jako ostateczne, rękopis nie jest zaś poglądową ilustracją, lecz równoprawnym sposobem prezentacji obiektu badań. Badam zatem dostępną kopię (przekaz) tekstu średniowiecznego (na fotografii rękopisu) wraz z najnowszą dostępną propozycją jej odczytania.

Samo uczynienie obiektem badań dostępnej kopii (w postaci fotokopii) i procedura porównywania rękopiśmiennego zapisu z propozycjami wydawców powoduje, że w obszarze badań pojawia się świadomość i intencja kopisty w zestawieniu z domniemaną świadomością i intencją autora oryginału; w dalszej części tego szkicu pozwolę sobie z tej perspektywy spojrzeć na wielokrotnie już analizowany fragment. Średniowiecznemu kopiście, kopiście Kazań świętokrzyskich w szczególności, przypisuje się różne kompetencje - od przepisywacza, którego domniemane błędy trzeba wywabiać, by dostrzec zakryte za nimi intencje autora - po mutatora, który tekst uzupełnia, zmienia, poprawia. Ta ostatnia rola niekiedy umyka badaczom, warto więc może przypomnieć opinię wydawców z 1934 roku (Łosia i Semkowicza): 
Badanie polskich rękopisów średniowiecznych poucza nas, iż żaden ówczesny kopista nie odpisywał oryginału zupełnie wiernie: każdy z nich wprowadzał mimowolnie lub umyślnie różne zmiany w pisowni, w fonetyce, w końcówkach form deklinacyjnych lub koniugacyjnych, nieraz wręcz zastępował starsze formy nowemi, niekiedy zmieniał wyrazy, słowem pod wielu względami tekst modernizował. Z góry też przyjąć należy, że robił to i przepisywacz naszych Kazañ ${ }^{9}$.

Poprawianie przepisywanego tekstu było przez średniowiecznych uznawane za nieodłączny element pracy kopisty; miał on nie tylko prawo, ale wręcz obowiązek poprawiania, co najlepiej pokazują uwagi przypisywane urodzonemu w 1235 roku Hugonowi z Trimbergu, autorowi traktatu Vita beate Virginis Marie et salvatoris rhytmica, który, jak obserwował Tadeusz Dobrzeniecki „w prologach do każdej księgi zwraca się do wykształconych czytelników z prośbą o poprawienie jego błędów"10. Traktat Vita, datowany na XII-XIII wiek, był w średniowieczu bardzo rozpowszechniony - podobnie jak reprezentowane w nim poglądy na temat roli czytelnika-kopisty. Oczywiście docierały one także na ziemie polskie - choć w polskich tekstach wyrażone wprost są te myśli dopiero w jedynej zachowanej do naszych czasów późnej kopii Rozmyślania przemyskiego: „Przeto zazdrościwy czci ni ma mi uwłoczyć, bo każdemu dana jest moc tych ksiąg polepszać, jako jego wola <... >"11. W innym miejscu - również wzorem Vita - średniowieczny pisarz wzywa uczonych mężów, by, znalazłszy błąd, poprawili go lub księgi spalili: „A przeto proszę mężow uczonych, najdąli to to isto być przeciw drodze prawdy, aby poprawili albo owszeją odezwali, albo jestli jem to lubo, aby wszytki księgi zeż $<\mathrm{g}>$ li, aby zazdrościwy mnie nijeden w tym nie uwłoczył ani ktory zły człowiek ni miał sie naśmiewać"12.

Pytając zatem o rolę kopisty Kazań świętokrzyskich, przeanalizowałem ponownie już nie tylko wprowadzoną przez niego do tekstu inter-

${ }^{9}$ Kazania tzw. świętokrzyskie, wyd. i oprac.: J. Łoś i W. Semkowicz, Kraków 1934, s. 44; podkreślenie moje - TM.

${ }^{10}$ T. Dobrzeniecki, Łacińskie źródta „Rozmyślania przemyskiego”, [w:] Średniowiecze. Studia o kulturze, t. 2, Wrocław 1969, s. 202.

${ }^{11}$ Rozmyślanie przemyskie, transliteracja, transkrypcja, podstawa łacińska, niemiecki przekład, wyd.: W. Twardzik i F. Keller, t. 1-2, Weiher-Freiburg i. Br 1998-2000; cytowany fragment karty 43 (t. 1.), w. 18-21.

12 Tamże, k. 174, w. 7-14. Odpowiada temu następujący fragment Vita: „Illud autem deprecor a viris litteratis,/ Ut haec sique reperint, quae viam veritatis/ Excedant, illa corrigant vel penitus abradant, / Vel, si placet, totum librum combustioni tradant. Sic invidus non habet hic locum detrahendi/ Nec aemulus inveniet causam hic mordendi./ Nam cuilibet conceditur potestas corrigendi/ Librum istum vel, si placet, totum abradendi.", cyt. za: T. Dobrzeniecki, dz. cyt., s. 203. 
punkcję (że interpunkcja pochodzi od przepisywacza nie mam wątpliwości, ale to temat na osobne rozważania ${ }^{13}$ ), ale także całą listę miejsc w rękopisie wskazanych przez Łosia i Semkowicza pod wspólnym hasłem „omyłki i poprawki”. Sposób patrzenia tych znakomitych badaczy na ślady działalności kopisty zdeterminowany był także przyjętą przez nich perspektywą: szukając argumentów na starość oryginału, przeprowadzali oni w rozdziale „Czas powstania Kazañ" 14 dowód, że są one kopią. Z tego punktu widzenia interesujący nas w dalszej części niniejszego wywodu początek „Kazania na objawienie Pańskie” (karta c, strona verso, wiersze 15-22) dostarczył im interesujących danych, lakonicznie podsumowanych: „cv 18. Pisarz niepotrzebnie napisal powtórne Gich, co też wykreślił" 15 .

Przyjęty w niniejszych rozważaniach szkicu sposób patrzenia na tekst każe na ten fragment zwrócić szczególną uwagę:

Transliteracja BN:

$<><\mathrm{i}>$ natus est rex iudeorum ? $\mathrm{s}^{\mathrm{u} \sigma \mathrm{ti}}$

$<>$ troiaky skut $^{\mathrm{rk}} \cdot$ znameniti $\cdot$ pocazu $^{\{\mathrm{ie}\}}$ vtih uethreh

$\mathrm{c}^{\mathrm{ro}}$ leh poganskih $\bullet$ gih zødne $\mathrm{c}^{\mathrm{ro}}$ leuicha de $\mathrm{d}^{\mathrm{e}} \mathrm{uic} \varnothing$ porodenego

pitane $\bullet$ Gih $v^{\text {er }}$ ne kzøzicha pocoy ${ }^{\text {ne }\{g o\}}$ posna $\left.{ }^{\{\text {ne }}\right\}$ ? [|Gih|] vidi

mus stellam eius in oriente $\cdot$ agih rihle $=\left\{<\ldots o>\mathrm{d}^{\text {re }}\right\} \mathrm{c}^{\text {rol }}$ a mocnego odarouane

ubi •et uenimus cum muneribus adorare dominum $\bullet$ ymoui ew ${ }^{\text {angelista }} \mathrm{s}^{\mathrm{u} \varnothing} \mathrm{ti}$ podob $^{\text {ra }} \mathrm{ze}^{\mathrm{m}}$ trsy $\mathrm{c}^{\mathrm{ro}}$ lew poganskih Gde $\mathrm{iesc}^{\text {ec }} \bullet$ ienze sø narodil crol zidowsky?

„Wizualizacja”:

\section{< Ubi est, qu>i natus est rex Iudeorum?}

Święty < ewanjelista> trojaki skutek znamienity pokazuje w tych we trzech krolech pogańskich:

jich żądne krolewica dziewicą porodzonego pytanie, jich wierne księżyca pokojnego poznanie (vidimus stellam eius in oriente), a jich rychłe $<$ i szcz $>$ odre krola mocnego odarowanie (ubi et venimus cum muneribus adorare Dominum).

I mowi ewanjelista święty pod obrazem trzy krolew pogańskich: Gdzie jeść teć, jenże się narodzil, krol żydowski?

\footnotetext{
13 Por. przyp. 6.

14 Dz. cyt, s. 42.

15 Tamże, s. 43.
} 
Ewangeliczne pytanie Ubi est, qui natus est rex Iudeorum i jego polskie tłumaczenie stanowią, jak widać, klamrę dla trójkowej struktury, odsyłającej do tych miejsc Ewangelii, gdzie cytuje ona wypowiedzi królów. To odesłanie odbywa się za pomocą doskonale paralelnych konstrukcji nominalnych, zbudowanych wokół rzeczowników odsłownych pytanie - poznanie - odarowanie, wg schematu: przydawka zaimkowa + przydawka rzeczowna (rzeczownik nazywający Jezusa w dop. z przydawką w postpozycji). Każdej z tych konstrukcji odpowiada łaciński cytat. Pytaniu odpowiada tytułowe pytanie (pisarz zacytował je na początku, więc nie przypomina go tutaj), poznaniu oraz odarowaniu - inne fragmenty pisma, które pisarz cytuje natychmiast, wprowadzając je, a raczej wstawiając do tekstu bez żadnych sygnałów tekstowych (bez obróbki strukturalnej). Decyzję o ich związku z tekstem musi podjąć badacz składni - od tej decyzji zależy wszak interpunkcja transkrypcji.

Proponując $w$ transkrypcji po poznaniu oraz odarowaniu postawienie dwukropka, zasugerowaliśmy, że lacińskie wtręty stanowią bezspójnikową strukturę podrzędną, dopowiadającą (to właśnie sugeruje dwukropek), stawianie zaś po nich przecinka (zamiast proponowanych w Chrestomatii staropolskiej średników ${ }^{16}$ ), pokazuje nierozerwalność struktury, współrzędność cząstek rozpoczynanych od zaimka jich, będących z punktu widzenia składni - strukturą szeregową, wyliczeniem wprowadzonym przez liczebnik trojaki (skutek). Cieszę się, że ta propozycja została uwzględniona w najnowszym wydaniu wzorem „Multimedialnej biblioteki".

Nie jest to przecież jedyna możliwa interpretacja składniowa tego fragmentu. Czas prześledzić rękopis: to niezwykłe miejsce tekstu. Pisarz, zapisawszy jich żadne krolewica dziewica porodzonego pytanie, jich wierne księzyca pokojnego poznanie chciał od razu kontynuować strukturę retoryczną wprowadzoną zaimkiem jich; zapisał ten zaimek nawet, poprzedzając punktem (kropką), po czym zapisany wyraz skreślił, wprowadzając zdanie łacińskie. Widać więc wyraźnie, że w intencji piszącego łaciński wtręt jest chyba jedynie zgromadzeniem materiału; nie należąc do kazania, jest nawiasowym uzupełnieniem, odesłaniem do właściwego miejsca Ewangelii. To skreślenie - będące dotąd (od czasów uwag Łosia i Semkowicza) tylko jednym z wielu dowodów na to, że mamy do czynienia z kopią każe zapytać, czy piszący (w rozumieniu: twórca rękopisu,

${ }^{16}$ Kazania świętokrzyskie, [w:] W.Wydra, W.R. Rzepka, Chrestomatia staropolska. Teksty do roku 1543, Wrocław 1984, s. 89-96. 
dostępnego nam przekazu) rozumiał strukturę retoryczną kazania; czy pisząc jich antycypuje treści późniejsze (czy możliwe, aby kopista ogarniał większe fragmenty tekstu przed ich przepisaniem?), czy tylko przeskakuje wzrokiem w niewłaściwe miejsce tekstu? A może jest jeszcze inaczej? Może ktoś, pracując nad tekstem, na marginesie dopisał odpowiednie fragmenty pisma, a następny pisarz - ten, spod którego ręki wyszedł badany rękopis - wciągnął je do tekstu? Czy byłyby to zatem kolejne w tym tekście ${ }^{17}$ glosy?

Decyzja o przytoczeniu łacińskich wtrętów burzy układ, zakłóca paralelizm (uzupełniony rytmem i rymem), bo pierwsza $\mathrm{z}$ równoległych fraz nominalnych pozostaje bez łacińskiego uzupełnienia w tym miejscu, co najlepiej pokazuje wizualizacja tego tekstu bez domniemanych glos:

\section{<Ubi est, qu>i natus est rex Iudeorum?}

Święty <ewanjelista> trojaki skutek znamienity pokazuje w tych we trzech krolech pogańskich:

jich żądne krolewica dziewicą porodzonego pytanie, jich wierne księżyca pokojnego poznanie a jich rychłe <i szcz>odre krola mocnego odarowanie

I mowi ewanjelista święty pod obrazem trzy krolew pogańskich: Gdzie jeść teć, jenże się narodzit, krol żydowski?

Wtedy widać, jak obróbką retoryczną ogarnięto tu większy fragment tekstu: Te ściśle paralelne trzy struktury z obu stron: przed i po otoczone są również podobnymi do siebie, choć zda się celowo różnicowanymi zdaniami:

Święty <ewanjelista > trojaki skutek znamienity pokazuje w tych we trzech krolech pogańskich,

I mowi ewanjelista święty pod obrazem trzy krolew pogańskich.

Zdania te właściwie mają identyczny sens, zróżnicowane są jedynie formalnie:

- wyborami leksykalnymi: czasownikowi mówienia pokazuje odpowiada zapewne synonimiczna konstrukcja mowi pod obrazem,

- szykiem czasownika (po podmiocie, przed podmiotem),

${ }^{17}$ W wydaniu BN Wiesław Wydra sformułował hipotezę, że występujące w Kazaniach świętokrzyskich tzw. „noty” są glosami. Por. „Kazania świętokrzyskie”. Nowa edycja..., s. 51. 
- szykiem składników grupy podmiotu (święty ewangelista - ewanjelista swięty)

- składnią konstrukcji nadrzędno-podrzednych: grupy werbalnej (pokazuje co w czym) i nominalnej (pod obrazem czego), w których występują wyrażenia zbieżne leksykalnie ( $w$ tych we trzech krolech pogańskich - trzy krolew pogańskich). Wreszcie te paralelne zdania okalające są także otoczone strukturami identycznymi, jakimi są łacińskie motto i jego tłumaczenie. To najpełniej pokazuje „wizualizacja”. Wydaje się, że konkluzję Wiesława Wydry: „Fragmenty te (a może i jeszcze inne teksty lacińskie w Kazaniach) zapewne nie należą do pierwotnego tekstu Kazań świętokrzyskich. Naruszają wysoki kunszt w sferze stylistyczno-językowej organizacji wypowiedzi, ich artyzm (...). W tym momencie całą ta artystyczna konstrukcja kunsztownej prozy wali się i zanika"18 w sposób szczególny można odnieść do tego miejsca $\mathrm{Ka}$ zania na objawienie Pańskie.

Jeśli zatem zdania $\mathrm{z}$ Ewangelii

(vidimus stellam eius in oriente),

(ubi et venimus cum muneribus adorare Dominum).

uznamy rzeczywiście za glosy (a takich w innym miejscu wskażemy jeszcze w Kazaniach świętokrzyskich kilka), postawić będzie trzeba ponownie pytanie o obiekt badań. Na ile te łacińskie cytacje są zintegrowane, także składniowo, z tekstem głównym? Odpowiedź, jak każda interpretacja składniowa, ma natychmiastowe konsekwencje w interpunkcji wstawianej przez nas do transkrypcji. Zatem: jeśli uznać te fragmenty za glosy, podobnie jak ,noty” wskazane przez Wiesława Wydrę, czy prezentować je należy w transkrypcji ,jednym ciągiem" (jako element tekstu), czy też nie (sygnalizując, że są elementem dostępnego nam przekazu)?

Funkcjonalnie są to nawiasowe dopowiedzenia, przypomnienia właściwego cytatu z Pisma Świętego. Zatem można by się zastanowić, jakiej użyć interpunkcji. I tu pojawia się zasadniczy problem. Mimo że od dawna postuluje się opracowanie nowych zasad wydawania tekstów staropolskich, mimo że praktyka wydawnicza odeszła daleko od dyrektyw sformułowanych przed kilkudziesięciu laty, wciąż próbujemy stosować nieliczne uwagi autorów projektu zasad dotyczące interpunkcji, które można streścić następująco: stosować wspótczesna i z umiarem, nie używając niczego poza przecinkiem, kropka i średnikiem ${ }^{19}$.

${ }^{18}$ W. Wydra, dz. cyt., s. 49, podkr. moje - TM.

${ }^{19}$ W Zasadach... czytamy: „W wypadkach takich w transkrypcji stosujemy interpunkcję zgodną z obowiązującymi dziś zasadami ortograficznymi, ale w sposób oszczędny, 
Gdyby kierować się chęcią oddania rozpoznanej w tekście struktury, glosy należałoby wprowadzać (pokazywać w edycji tekstu) na kilka sposobów:

- jeśli rozbijają strukturę tekstu, warto by się może zastanowić nad inną czcionką,

- jeśli są sygnalizowane spójnikiem, to zgodnie z jego składnią i przyjętą interpunkcją (jak Wacław Twardzik we wspomnianej edycji Rozmyślania przemyskiego ${ }^{20}$ ), może także inną czcionką,

- jeśli są wprowadzane bezspójnikowo, a stanowią dopowiedzenie czy element synonimiczny - kolejnym typem nawiasu, choć ten (kwadratowy i ostry) jak wiadomo, zarezerwowany jest dla innych celów. Rzecz tutaj tylko sygnalizuję, pozostawiając szczegółowe jej omówienie na inną okazję. Podobnie jak kwestię pozostawiania w transkrypcjach znaków interpunkcyjnych z rękopisów. W transkrypcjach właśnie, bo na transkrypcjach - traktowanych jako obiekt badań - pracują najczęściej osoby zajmujące się treścią, retoryką, przynależnością kulturową. Winny mieć zatem dostęp do znaków, będących świadectwem intencji pisarza lub kopisty, w wypadku interpunkcji kazań świętokrzyskich do znaków, będących, jak mówi Jan Godyń „swoistą partyturą do wygłoszenia"21.

Jeśli uznamy, że w Kazaniach świętokrzyskich są glosy, czy powinniśmy wyodrębniać je w transkrypcji? A jeśli tak, to które? A co z miejscami, w których mamy do czynienia z takim uzupełnieniem tekstu, co do którego nie potrafimy rozstrzygnąć, czy jest naprawieniem omyłki pisarskiej powstałej przy kopiowaniu czy glosą, wprowadzającą element nieobecny w oryginale? Wracając do omawianego tu dokładniej miejsca tekstu - jeszcze raz spójrzmy na trzy paralelne konstrukcje podrzędne:

jich żądne krolewica dziewicą porodzonego pytanie,

jich wierne księżyca pokojnego poznanie,

a jich rychłe krola mocnego odarowanie.

Czytam: a jich rychte krola mocnego odarowanie, bo dopiero po uzupełnieniu tekstu o glosę widoczną na marginesie rękopisu ostatni werset brzmi: jich rychte i szczodre krola mocnego odarowanie.

wprowadzając znaki tylko jako element niezbędnej interpretacji tekstu z możliwym unikaniem znaków ekspresyjnych takich jak wykrzyknik i myślnik.” (dz. cyt., s. 41).

${ }^{20}$ Por. przyp. 11.

${ }^{21}$ J. Godyń, Retoryka w pieśni pasyjnej Wtadystawa z Gielniowa, „Psatterzu floriańskim” $i$ „Kazaniach tzw. świętokrzyskich”. (Funkcje średniowiecznej interpunkcji), „Ruch Literacki”, 37:1996, z. 6, s. 683. 
Paralelizm, wzmocniony rymem, jest zupełny: realizowany na każdym poziomie: szyku, relacji składniowych, brzmienia. Można wskazywać odpowiadające sobie w odpowiednich pozycjach tworzące triadę słowa: krolewica - księżyca - krola, pytanie - poznanie - odarowanie, a także: żadne - wierne - rychte. Ten zamysł artystyczny uzupełnienie $i$ szczodre raczej burzy, niż dopełnia. Ponadto rozbija doskonały układ trójkowy, niepotrzebnie dublując jeden z elementów triady. Oczywiście ma sens, logicznie pasuje do tekstu, ale nie jest nie tyle jego poprawą, co dopełnieniem. Zastanawiam się, czy nie można myśleć o całym tym fragmencie tak:

Pierwotna struktura bez uzupełnień łacińskich została uzupełniona o marginalne glosy, przywołujące łacińskie wersety. Te glosy (zważywszy ich wielkość, zapewne marginalne), wciągnięte przez kopistę do tekstu głównego, zakłóciły jego rytm, zamazały retoryczne opracowanie. Kolejny kopista-mutator, wprowadzając uzupetnienie $i$ rychte nie odczuwał już tego jako psucia struktury - była już ona zatarta wprowadzeniem łacińskich glos. Czyżby była to kolejna poszlaka, że Kazania świętokrzyskie są kopią z kopii? Z pewnością można powiedzieć, że kopista - któryś z kopistów - wykonał przy Kazaniach pracę daleko przekraczająca obowiązki przepisywacza.

Zwłaszcza, że oprócz zaproponowanych przez Wiesława Wydrę i wskazanych powyżej miejsc jest w Kazaniach świętokrzyskich jeszcze i kilka, które podejrzewać można, że trafiły do tekstu podczas kolejnych przepisywań. Nie ma czasu tutaj na omówienie ich wszystkich. Moje wątpliwości budzi na przykład uzupełnienie ilkoż do widzenia, dwukrotnie, w tym raz na marginesie zapisane w Kazaniu VI, w kontekście domniemanych glos zastanawiam się też nad zdaniami objaśniającymi, zwłaszcza jeśli są to struktury wtrącone, jak Galaa wyprawia się miasto plwiacych, to je nieustawicstwo ludzi grzesznych. Zdanie to znalazło się wewnątrz bardzo skądinąd rozbudowanego cytatu z Księgi Sędziów, wprowadzonego strukturą Czcie się tako we Księgach Sędskich. Warto przy tym zauważyć, że cały ten, będący jednym zdaniem, fragment mógłby być zaliczony do listy dowodów na intelektualny charakter kazań i wysokie wymagania stawiane ich odbiorcom.

Czcie się tako we Księgach Sędskich: Anjeł, prawi, święty zstąpi do Galaa ku synom israelskim - Galaa wyprawia się miasto plwiących, to je nieustawicstwo ludzi grzesznych - i zmo<wił to> słowo: Sam, prawi, przez mię przysiągl jeśm, iż wam chociał <jeśm podać zi>emię wrogow waszych, iżbyście ku jich bogom $<$ nie chodzili, to > go jeście nie uczynili, ale potępiwszy Boga waszego < wszemo- 
gącego, pogańskim> bogom modłę jeście wzdawali, przetoż, prawi, dam was $<$ wrogom waszym $>$ i w jich włodanie.

W „Multimedialnej Bibliotece” zdecydowaliśmy się na ujęcie tego wtrącenia w myślnikach, całą zacytowaną strukturę uznając za jedno zdanie. Cieszę się, że w takiej postaci znalazło się ono i w wydaniu BN. W poprzednich wydaniach dzielono je nawet na pięć zdań. Nie czas jednak tu na szczegółowe objaśnienia. Warto tylko zauważyć, że jeśli badania są prowadzone na transkrypcji i to ją badacz przyjmuje jako obiekt analiz, w zależności do wyboru edycji może mieć do czynienia z inną rzeczywistością tekstową.

Jestem przekonany, że postawienie w centrum rozważań roli kopisty - kopistów poprowadzi do dyskusji nad innymi, nie dostrzeżonymi dotąd śladami jego działalności. Przy czym nie zawsze będą to działania twórcze, uzupełnienia. I tak na przykład zastanawiam się, czy w zdaniu „a trzecie idzie tobie ubogi, iżby ty w ubostwie nie styskował” $\mathrm{z}$ „Kazania na narodzenie Pańskie" kopista omyłkowo nie pominął wyrazu krol. Nie ma takiego przeoczenia w żadnym z ponad 10 analogicznych zdań w tym kazaniu (typu: idzie tobie król śmierny, idzie tobie król prawdziwy), wśród których nie brakuje i konstrukcji idzie tobie krol ubogi (cr 36, cv 12). Zauważmy, że jeśli zdecydujemy się na to uzupełnienie, zakładamy, że wyraz ubogi w Kazaniach występuje wyłącznie jako przydawka (ubogi krol, krolewic, dziewica), jeśli pozostawimy bez uzupełnienia, wówczas zakładamy, że przymiotnik ubogi jest już zsubstantywizowany, może wystąpić jako podmiot bez rzeczownika, a nie tylko jako człon określający. Każda bowiem nasza decyzja interpretacyjna w odniesieniu do rozpoznania śladów działalności kopisty modyfikuje to, na co patrzymy - obiekt badań.

Sprawa z omawianym wcześniej fragmentem, w którym zaproponowałem rozpoznanie glos, nie jest łatwa, bo, jak często w Kazaniach świętokrzyskich bywa, połączenia kolejnych członów składniowych (tu pomiędzy zdaniem polskim a łacińskim wtrętami) nie są sygnalizowane żadnym sygnałem zespolenia. W strukturze składniowej Kazań świętokrzyskich przeważają bowiem połączenia współrzędne. Ma to kapitalne znaczenie dla językoznawcy. Patrzy on bowiem na tekst zupełnie innymi oczyma, niźli literaturoznawcy. Ich spojrzenia spotykają się wprawdzie na moment przy kwestiach retorycznych, które dla literaturoznawcy stoją w centrum uwagi, a lingwista umieści je w pogranicznej dziedzinie stylistyki językoznawczej. Koncentruje się bowiem na czym innym. Istotą perspektywy historycznojęzykowej (czy raczej historycznojęzykoznawczej) jest to, że badacz, patrząc na indywidualny tekst, zadaje sobie py- 
tanie o stan języka, który ten tekst reprezentuje. Każdy tekst jest dla niego przykładem stanu języka. Szuka w nim tego, co nieindywidualne, co reprezentatywne dla dziejowego mementu rozwoju języka. Teksty najstarsze są przez językoznawców przepatrywane z najwyższą starannością: i tak niemało zjawisk w gramatyce historycznej języka polskiego obrazowanych jest wyłącznie lub niemal wyłącznie przykładami z Kazań świętokrzyskich (imperfecta i aorysty, formy zaimkowe typu togo, tomu, przymiotniki w odmianie prostej).

Historyka języka polskiego interesuje zatem przede wszystkim proces rozwoju. Dla badacza składni Kazania świętokrzyskie są - jako pierwszy większy tekst polski - bezcennym świadectwem największego przełomu, jaki może się dokonać w dziejach każdego języka: momentu dziejowego, w którym tenże język dobija się do postaci pisanej, wchodzi w okres piśmienny. Zawsze zresztą decydują o tym czynniki zewnątrzjęzykowe, jak w wypadku naszego języka szeroko opisywana zmiana nastawienia Kościoła do polszczyzny, jaka następuje od połowy XIII wieku. W momencie przełomu język stoi przed koniecznością ustalenia relacji brzmienie - znak, przed koniecznością wielkich zmian semantycznych i leksykalnych (potrzeba wyrażenia w nim znaczeń związanych ze sferą religii, Kościoła, życia społecznego), wreszcie - przed koniecznością głębokich przemian w zakresie składni, wręcz rewolucyjnych, jeśli „wybicie się na pismo" dokonuje się za sprawą konieczności przeszczepienia obcych wzorów, dokonania tłumaczeń, a w końcu redagowania tekstów według wypracowanej w obrębie innego języka zasad o wielowiekowej tradycji. Tekstem mówionym w ,języku przedpiśmiennym” rządzi zasada dostawiania kolejnych elementów, z dzisiejszej perspektywy nazywana współrzędnością. Wyznacza ona kierunek organizacji tekstu: powtarzanie elementów podobnych, multiplikowanie struktur. Przeorganizowanie składni ze względu na możliwości, jakie daje pismo, i wymagania, jakie stawia konieczność tłumaczenia tekstów, to trudna droga: jak trudne było to przejście najlepiej pokazują Kazania gnieźnieńskie, w których praca nad strukturami podrzędno-nadrzędnymi, skutkująca często piętrowym gromadzeniem elementów łączących, trwa w całej pełni. Kierunek tej pracy, dążność do tworzenia „większych konstrukcji syntaktycznych”, konstrukcji spójnych, z wyraźnymi elementami strukturalizacji językoznawca badający teksty dawne musi zauważyć.

Kazania świętokrzyskie są jeszcze bardzo zakotwiczone we współrzędności. Są świadectwem pewnego paradoksu: z jednej strony mamy wielki artyzm, właściwie dziś już niekwestionowany przez badaczy, z drugiej 
strony ten kunszt jest osiągany na poziomie - ze składniowego punktu widzenia - zupełnie elementarnym. Jest to język złożonych kombinacji z całych ciągów podobnych i paralelnych elementów. W tym sensie retoryka, wynikająca z przeszczepienia na grunt polski osiągnięć ars dictandi, jest tu ponad gramatyką ${ }^{22}$. Ponad gramatyką nie znaczy, że tekst jest niegramatyczny. Składniowiec nigdy nie pomyśli nawet, że można budować jakiekolwiek wypowiedzenie w taki sposób, by retoryka pozwalała na niegramatyczność zdania. Językoznawca tak absolutnie pomyśleć nie może. Mówiąc „retoryka ponad gramatyką" nie sygnalizowałem zawieszenia reguł gramatycznych, ale pokazywałem, że korzystając z języka, w którym dopiero rozpoczęta była praca nad zaszczepieniem w pisemnej polszczyźnie licznych wariantów zdania złożonego podrzędno-nadrzędnie, można było tworzyć teksty w pełni realizujące postulaty ars dictandi. I dlatego mówiłem, że zasada rządzaca budowa tego tekstu (zbioru tekstów) i tworzacych go wypowiedzeń nie jest (...) sktadnia, lecz przede wszystkim retoryka (majaca oczywisty wpływ na kształt sktadniowy) ${ }^{23}$.

Okazuje się bowiem, że naturalna w tej fazie dziejów języka dominacja współrzędności, z którą wiąże się powtarzalność, łatwo poddaje się obróbce, które rezultatem są np. wyliczenia i paralelizmy.

Tyle spojrzenie historyka języka.

Wchodząc na obszar graniczny, obserwowany głównie przez literaturoznawców, ale z konieczności pozostający także w polu widzenia językoznawców, zatem w obszar retoryki, wypada jeszcze powiedzieć, że $z$ lingwistycznej perspektywy widziana retoryka budowała się w dziejach (nie chcę tu wchodzić w kompetencje znawców tej dziedziny) na bardzo pierwotnych podstawach: powtarzalność prowadzi w stronę wyliczeń, paralelizmów, a te w stronę struktur wyższych, formulicznych, później ujmowanych w całe traktaty. Składnia retoryczna wypracowała elementy wzmacniające efekt powtarzalności, w postaci rytmu i rymu, co zawieszone jest w oralności, związanej ściśle z mnemotechnicznością.

${ }^{22} \mathrm{~W}$ tej części szkic ten jest także odpowiedzią na wygłoszony podczas tejże samej konferencji i opublikowany w niniejszym tomie artykuł polemiczny prof. Krzysztofa Obremskiego, której to polemiki osią jest moje sformułowanie „retoryka ponad gramatyką (składnią)” (Por. „Kazania świętokrzyskie”. Nowa edycja..., s. 70). W toku dyskusji polemista zdecydował się na wycofanie swoich racji dotyczących mojej interpretacji fragmentu „a są slowa syna”, stąd i ja rezygnuję z odpowiedzi na tę część polemiki, podtrzymując sformułowaną we wstępie do wydania BN interpretację (tamże, s. 71-72). Jednocześnie dziękuję prof. Obremskiemu za przesłanie tekstu polemicznego przed wygłoszeniem, co zainspirowało mnie do rozważań na temat różnic w postrzeganiu obiektu badań przez literaturoznawców i lingwistów.

23 Tamże, s. 61. 
Pytanie, na które językoznawca nie zna odpowiedzi, w niektórych bowiem obszarach musi przyjąc dostępne ustalenia literaturoznawcze brzmi: Czy oczywiste i przyjmowane przez badaczy za pewnik - wydawało mi się dotąd w świetle licznych publikacji - przeświadczenie, że ukształtowaniem tekstu Kazań świętokrzyskich rządzi właśnie ars dictandi, co w odniesieniu do nich pokazywali i pokazują najznamienitsi historycy literatury $^{24}$, zawiera bardzo poważną lukę? Dlaczego nie postawiono wcześniej pytania, czy „świętokrzyską sztukę wymowy kształtuje poetyka immanentna wersetów"25?

To prowadzi nas z powrotem do głównego przedmiotu niniejszych rozważań: Kazań świętokrzyskich postrzeganych jako obiekt badań. Zda się, że badacz nigdy nie widzi tego obiektu samego w sobie, postrzega go bowiem automatycznie przez filtry - wiedzy własnej, podstaw swojej dziedziny, wiedzy wspólnej.

I tak, jeśli literaturoznawcy zgodzą się z przedstawioną przez badacza retoryki (Krzysztof Obremski) hipotezą, że „to Księga Psalmów jest tą, w której składnia zdań Kazań świętokrzyskich znajduje wyjaśnienie swej wyjątkowości na tle średniowiecznej prozy polskiej”, a co za tym idzie w charakterystycznym dla tej poetyki „prawie zupełnym braku wyrazów służących nawiązaniu między wersetami”, językoznawca będzie być może musiał zweryfikować swoje patrzenie na Kazania świętokrzyskie, jako na jedyny tekst będący świadectwem owej naturalnej dla tej fazy rozwoju składni języka: dominacji współrzędności nad relacjami podrzędnonadrzędnymi. Dopóki jednak taka radykalna zmiana w patrzeniu na $\mathrm{Ka}$ zania świętokrzyskie nie nastąpi, badacz składni będzie w polskich fragmentach kazań widział świadectwo momentu dziejowego w historii polskiego zdania, świadectwo czasu, w którym powstały.

Podsumowując, wypada powiedzieć, że sprawa Kazań świętokrzyskich jako obiektu badań jawi się jako problem w najwyższym stopniu skomplikowany, a przede wszystkim otwarty:

- z jednej strony nowo postawiony problem kopii (kopii z kopii) nasuwa myśl o konieczności weryfikacji badań nad kazaniami jako integralną całością; wystarczy uświadomić sobie, że jeśli zgodzimy się na

${ }^{24}$ A także językoznawca - Ewa Ostrowska w swoim znakomitym, osadzonym w materiale językowym i niemal w całości aktualnym studium. Por. E. Ostrowska, Kompozycja i artyzm językowy „,Kazań świętokrzyskich”, [w:] taż, Z dziejów języka polskiego i jego piękna. Studia i szkice, Kraków 1978, s. 41-100.

${ }^{25}$ Sformułowanie Krzysztofa Obremskiego. Byłoby chyba dobrze, gdyby do tego wątku dyskusji włączyli się literaturoznawcy - taki jest sens i intencja mojego pytania (w żadnym razie erystyczne powołanie się na autorytety). 
hipotezę Wiesława Wydry, to obszerne fragmenty wskazane przezeń jako nienależące do tekstu pierwotnego staną się dla nas świadectwem erudycji kopisty, a nie autora. Już to pokazuje, że obiekt przestaje być jednolity: przed sobą mamy więcej niż jeden obiekt, za to jeden przekaz;

- z drugiej strony w całej ostrości staje przed nami fakt, że po stu latach pracy nad tym tekstem nadal sporo w nim miejsc niejasnych, a transliteracja i transkrypcja mają cechy interpretacji;

- wreszcie nadal trudno wskazać wiedzę wspólną; nowe wydanie, a i toczący się tu dzisiaj spór pokazują, w jak bardzo różny sposób mogą być interpretowane te same fakty językowe i tekstowe.

\section{Summary}

\section{The Holy Cross Sermons as an Object of Philological Analysis: Textual and Transmission Issues}

The author addresses issues pertaining to the philological analysis of the Holy Cross Sermons. He discusses in detail the functions and the significance of the transcription and transliteration of the original text, and of the photographs included in the critical edition. He stresses that the monument, as it has reached us, is a copy of a copy, and that the insertions and corrections there functioned as glosses in the original, and should be analysed as such. Moreover, Mika is of the opinion that all the results obtained in previous inquirvies should be verified in accord with this observation. 